\title{
Perubahan Iklim dan Aksi Menghadapi Dampaknya: Ditinjau dari Peran Serta Perempuan Desa Pagerwangi
}

\author{
M. Mustangin \\ Pendidikan Luar Sekolah, Universitas Pendidikan Indonesia. Jalan Dr. Setiabudhi No. 229, \\ Isola, Kota Bandung, Jawa Barat 40154, Indonesia \\ Email: mustangin1992@gmail.com
}

Received: 16 February 2017; Revised: 28 February 2017; Accepted: 1 March 2017

\begin{abstract}
Abstrak
Penelitian ini bertujuan untuk menganalisis pola keterlibat perempuan dalam rangka mendukung upaya pengelolaan lingkungan untuk mengatasi perubahan iklim tersebut. Penelitian ini menggunakan pendekatan kualitatif, dengan melakukan wawancara mendalam dan mengkaji dokumen terkait perubahan iklim. Temuan penelitian menunjukkan bahwa adanya keterlibatan awal perempuan dan organisasi perempuan dalam rangka mensukseskan aksi mitigasi dan adaptasi perubahan iklim di desa pagerwangi. Pola keterlibatan perempuan dimulai dari awal peningkatan kesadaran akan ancaman perubahan iklim dan keterlibatan dalam proses pendidikan masyarakat antar perempuan untuk ikut serta terlibat. Dan akhirnya, keterlibatan perempuan dibutuhkan untuk mencapai tujuan dari menghadapi perubahan iklim.
\end{abstract}

Kata Kunci: keterlibatan perempuan, pengelolaan lingkungan, perubahan iklim

\section{Climate Change and Action to Face the Impact: Based on Women's Participation in Pagerwangi Village}

\begin{abstract}
This study aimed to analyze the pattern of women participation in order to support environmental management efforts to address climate change. This study used a qualitative approach, by conducting in-depth interviews and reviewing documents related to climate change. The research findings show that their early involvement of women and women's organizations in order to succeed mitigation actions and adaptation to climate change in the village pagerwangi. The pattern of women's involvement from the beginning of an increasing awareness of the threat of climate change and community involvement in the educational process among women to participate and be involved. And finally, women's involvement is needed to achieve the goal of addressing climate change.
\end{abstract}

Keywords: women's participation, environmental management, climate change

How to Cite: Mustangin, M. (2017). Perubahan iklim dan aksi menghadapi dampaknya: Ditinjau dari peran serta perempuan Desa Pagerwangi. Jurnal Pendidikan dan Pemberdayaan Masyarakat, 4(1), 8o-89. doi:http://dx.doi.org/10.21831/jppm.v4i1.13051

Permalink/DOI: http://dx.doi.org/10.21831/jppm.v4i1.13051 


\section{Jurnal Pendidikan dan Pemberdayaan Masyarakat, 4 (1), March 2017 - 81}

\section{Mustangin}

\section{PENDAHULUAN}

Perubahan iklim merupakan salah satu isu yang saat ini menjadi perhatian semua pihak. Sebagaimana diungkapkan oleh Boateng \& Boateng (2015) bahwa Perubahan iklim adalah masalah kebijakan publik terbesar di zaman ini. Mengenai perubahan iklim, United States Global Climate Change Programme (dalam Okoli \& Ifeakor, 2014) perubahan iklim didefinisikan sebagai reaksi ekstrem fenomena cuaca yang menciptakan dampak negatif pada sumber daya pertanian, sumber daya air, kesehatan manusia, penipisan lapisan ozon, vegetasi dan tanah, yang menyebabkan dua kali lipat dari konsentrasi karbon dioksida dalam ekosistem. Sedangkan Francis (2014) menyebutkan bahwa perubahan iklim adalah perubahan sifat statistik dari sistem iklim. Hal ini juga perubahan cuaca bumi termasuk perubahan suhu, angin. Perubahan iklim secara langsung berdampak negatif kepada manusia dan lingkungan sekitarnya. Sehingga memang perubahan iklim menjadi fokus semua pihak untuk mengatasinya.

Salah satu upaya dalam mengatasi perubahan iklim adalah dengan pengelolaan lingkungan agar dapat mengurangi dampak dari perubahan iklim tersebut. Pengelolaan lingkungan tersebut harus melibatkan semua pihak. Atas dasar kerjasama tersebut tujuan mengurangi dampak perubahan iklim akan tercapai. Aspek yang panting dalam pengelolaan lingkungan adalah dengan melibatkan seluruh masyarakat dalam seluruh aspek kegiatan pengelolaan lingkungan tersebut. Masyarakat menjadi aktor utama yang terlibat secara langsung dalam pengelolaan lingkungan tersebut. Pengelolaan lingkungan berbasis masyarakat dilakukan untuk mengelola lingkungan bersama masyarakat dengan meletakkan pemahaman terhadap lingkungan sebagai hal yang utama. Pendekatan dengan pengelolaan lingkungan berbasis masyarakat menurut Carter (dalam Hasani (2012) strategi untuk mencapai pembangunan lingkungan yang berpusat pada manusia, dimana pengambilan keputusan itu sepenuhnya menjadi tanggung jawab seluruh masyarakat.
Pengelolaan lingkungan berbasis masyarakat dapat dijalankan melalui pendekatan pemberdayaan. Strategi pemberdayaan masyarakat salah satunya adalah dengan meningkatkan kemampuan masyarakat untuk dapat berperan untuk perbaikan lingkungan dimana masyarakat itu tinggal. Artinya pemberdayaan masyarakat bertujuan untuk memberikan peluang kepada masyarakat untuk dapat mencapai pemecahan masalah yang dihadapi. Hal tersebut seperti yang diungkapkan oleh Kapitsa (dalam Sohail, 2014) pemberdayaan masyarakat berarti kekuatan untuk melakukan perubahan dalam masyarakat dengan menggerakkan sumber daya yang ada serta pemanfaatan peluang untuk perubahan dalam masyarakat. Pelibatan untuk mengelola lingkungan menjadi tanggung jawab seluruh masyarakat, sehingga tidak ada tuntutan berdasarkan gender dalam menjaga lingkungan. Pelibatan tersebut juga dapat dimainkan oleh perempuan sebagai bagian dari masyarakat dan juga memiliki tanggung jawab dalam pengelolaan lingkungan tersebut.

Program pegelolaan lingkungan akan terlaksana dengan baik jika ada pelibatan bersama seluruh masyarakat. Keterlibatan masyarakat tersebut diperlukan agar masyarakat memiliki posisi yang utama dimana mereka akan hidup di lingkungan tersebut sebagai tempat tinggalnya. Hal tersebut didukung oleh pernyataan Ife \& Tesoriero (2008) bahwa Keterlibatan atau partisipasi merupakan sebuah konsep sentral, dan prinsip dasar dari pengembangan masyarakat karena di antara banyak hal unsur keterlibatan terkait erat dengan gagasan HAM.

Keterlibatan atau partisipasi didefinisikan oleh Elhaq \& Satria (2011) bahwa Partisipasi adalah keikutsertaan setiap pihak yang terlibat dalam setiap tahapan kegiatan pembangunan. Pandangan lain mengenai partisipasi seperti yang diungkapkan oleh Chaesfa \& Pandjaitan (2013) Partisipasi adalah pencurahan aktifitas atau benda melalui suatu proses kegiatan bersama mencapai tujuan bersama.

Pengelolaan lingkungan berbasis masyarakat yang menempatkan strategi pemberdayaan masyarakat menjadikan partisipasi sebagai faktor yang dominan untuk 


\section{Jurnal Pendidikan dan Pemberdayaan Masyarakat, 4 (1), March 2017 - 82}

M. Mustangin

mencapai hasil yang diharapkan. Keterlibatan masyarakat yang berarti melibatkan perempuan dalam pelaksanaan pengelolaan lingkungan tersebut. Keterlibatan perempuan menjadi hal yang penting, sebagaimana dilihat peran perempuan yang juga mendominasi dalam kehidupan berumah tangga. Perempuan memiliki tugas mengelola segala sitem rumah tangga untuk dapat berjalan lebih baik. Aktivitas perempuan dalam rumah tangga sangat dominan dengan lingkungan dan tidak bisa dipisahkan oleh lingkungan.

Ada beberapa kajian yang membahas tentang Keterkaitan aktivitas perempuan dan lingkungan seperti halnya yang diungkapkan oleh Yuliana dan Dewy (2012) yang menceritakan aktivitas perempuan yang rela mengantri guna mendapatkan air bersih untuk keperluan sehari-hari, seperti memasak, mencuci, mandi bagi perempuan masyarakat Rawa Badak yang mengalami kesulitan akses air bersih, perjuangan mereka Untuk mendapatkan air bersih biasanya terpaksa membeli dari penjual air gerobak atau menunggu air PAM keluar, meskipun Air PAM yang tidak keluar dengan lancar dan harus rela mengantri lama. Selain itu laporan dari Widiarti dan Hiyama (2012) mengenai aktivitas pekerjaan perempuan untuk pengelolaan lungkungan di Desa Citarik, Sukabumi yang terlibat dalam kegiatan rehabilitasi hutan karena statusnya sebagai kepala keluarga atau menggantikan suaminya yang bekerja di tempat lain.

Ada empat alasana yang menyebabkan keterkaitan antara perempuan dan lingkungan menurut Dwi (dalam Sarwono, 2010) diantaranya adalah pertama, secara fisiologis perempuaan terlibat dalam waktu yang lebih lama dengan spesies kehidupan di mana perempuanlah yang merawat masa depan manusia. Kedua, posisi perempuan di wilayah domestik merupakan tempat bayi-bayi ditransformasikan menjadi makhluk kultural. Ketiga, psikologi perempuan sebagai ibu membuahkan cara berpikir yang lebih relasional, konkrit dibanding dengan lakilaki. Alasan terakhir, kaum perempuan yang bertanggungjawab terhadap wilayah domestik punya banyak andil dalam mengurangi jumlah sampah. Di sisi lain menurut (Astuti,
2012) Perempuan selalu bergaul akrab dengan produk-produk yang berdampak pada limbah dan pencemaran lingkungan, Misalnya limbah rumah tangga. Dengan demikian perempuan mempunyai peran sentral dan strategis dalam pengelolaan lingkungan. Upaya melibatkan perempuan dalam rangka pengelolaan sering dijumpai saat ini. banyak penelitian yang mengungkapkan proses pengelolaan yang sasaran utamanya adalah perempuan.

Pola aturan masyarakat yang sudah turun temurun telah diketahui keterlibatan perempuan dalam pengelolaan lingkungan, hal itu seperti yang diungkapkan oleh Chaesfa \& Pandjaitan (2013) Perempuan Indonesia mempunyai kebiasaan dalam mengelola lingkungan, terutama dalam hal pemeliharaan. Contoh kebiasaan perempuan dalam mengelola lingkungan seperti menyapu dua kali sehari, membuang sampah rumah tangga di tempatnya, dan melakukan pengelolaan sampah, seperti daur ulang sampah dan penggunaan kompos untuk pertanian.

Pengelolaan lingkungan untuk mengatasi perubahan iklim menjadi salah satu fokus yang ada di Desa Pagerwangi. Pengelolaan lingkungan dalam rangka adaptasi dan mitigasi dalam mengatasi perubahan iklim tersebut. Ketercapaian hasil dari pengelolaan lingkungan yang ada di Desa Pagerwangi ini juga tidak bisa lepas dari adanya keterlibatan perempuan yang turut berperan dalam menyukseskan program pengelolaan lingkungan berbasis masyarakat tersebut. Berdasarkan realita tersebut penelitian ini akan mengungkap pola keterlibatan perempuan dalam rangka pengelolaan lingkungan berbasis masyarakat tersebut.

\section{METODE}

Penelitian ini menggunakan penelitian kualitatif dengan jenis penelitiannya adalah studi kasus. Penelitian pendahuluan dilakukan dengan mencari data mengenai profil desa dengan penerima Penghargaan Kampung Iklim. Hal itu dikarenakan Desa yang menadapatkan penghargaan kampung Iklim merupakan desa yang masyarakatnya telah berhasil melakukan upaya adaptasi dan mitigasi perubahan iklim, sehingga desa tersebut 


\section{Jurnal Pendidikan dan Pemberdayaan Masyarakat, 4 (1), March 2017 - 83}

M. Mustangin

memiliki praktek pengelolaan lingkungan yang baik. Dari beberapa informasi yang didapat diketahui bahwa Desa Pagerwangi merupakan daerah yang mendapatkan penghargaan sebagai kampung iklim.

Lebih lanjut Penelitian ini dilakukan di Desa pagerwangi Kecamatan lembang Kabupaten Bandung Barat. Sumber data dibedakan atas sumber data primer dan sumber data sekunder. Sumber data primer didapat melalui wawancara yang mendalam kepada para informan. Wawancara yang mendalam dilakukan untuk mendapatkan data primer dengan pihak pengurus desa yang ikut bertindak sebagai pelaksana program pengelolaan lingkungan. Sedangkan Sumber data sekunder berupa dokumentasi dan arsiparsip resmi yang dapat mendukung hasil penelitian. Untuk mendapatkan data sekunder dilakukan dengan mengkaji beberapa dokumen yang terkait dengan pengelolaan lingkungan di Desa Pagerwangi.

\section{HASIL DAN PEMBAHASAN}

\section{Perubahan Iklim dan Pengelolaan Lingkungan Berbasis Masyarakat}

Perubahan iklim telah dicatat sebagai sebuah tantangan yang harus dihadapi oleh umat manusia. Meskipun demikian, manusia di seluruh dunia telah gagal untuk mengembangkan respon yang efektif dan signifikan terhadap perubahan iklim tersebut bahkan penelitian yang signifikan di masa lalu membuktikan bahwa orang-orang lebih memilih untuk tidak peduli terhadap perubahan iklim. Seperti yang diungkapkan oleh Redaksi Butaru (2011) Menyebutkan bahwa perubahan iklim terjadi dimasyarakat dan sudah terlibat dampaknya seperti perubahan garis pantai, namun masyarakat kurang peduli terhadap perubahan iklim tersebut. Selain itu Sagala, dkk (2014) juga menyebutkan bahwa masyarakat yang tahu perubahan iklim biasanya hanya mengetahu isu-isu umum, yang berarti mereka tidak tahu detail spesifik dari perubahan iklim dan dampaknya dalam jangka panjang, ahkan ada masyarakat dan para petani yang tidak tahu apa-apa tentang perubahan iklim, sehingga Masyarakat menganggap perubahan iklim bukan masalah prioritas, sehingga tidak ada program khusus dan upaya yang dilakukan oleh masyarakat tentang perubahan iklim.

Isu perubahan iklim menjadi perhatian banyak pihak seperti pihak Lokal, Nasional, Regional dan bahkan dunia Internasional seperti PBB lebih gencar melakukan program pembangunan berkelanjutan salah satunya berkaitan dengan perubahan iklim seperti mengurangi gas emisi yang dimulai tahun 2015 yang lalu.

Berbagai kejadian terkait dengan kondisi iklim yang tidak menentu seperti banjir, kekeringan, longsor, gelombang tinggi, dan peningkatan muka air laut semakin sering terjadi dengan intensitas yang semakin meningkat, sehingga menimbulkan korban jiwa serta kerugian ekonomi dan ekologi. Kondisi tersebut perlu disikapi tidak hanya oleh pihak Pemerintah atau orang-orang yang bergerak di bidang kelestarian lingkungan hidup, tetapi untuk seluruh masyarakat untuk memperkuat aksi nyata dalam menghadapi dampak perubahan iklim, Undang-Undang Nomor 17 Tahun 2004 tentang Protokol Kyoto Atas Konvensi Kerangka Kerja Perserikatan Bangsa-Bangsa Tentang Perubahan Iklim menyebutkan bahwa perubahan iklim bumi akibat peningkatan konsentrasi gas rumah kaca di atmosfer menimbulkan pengaruh merugikan terhadap lingkungan dan kehidupan manusia sehingga perlu dikendalikan sesuai dengan prinsip tanggung jawab bersama.

Upaya bersama dalam mengatasi perubahan iklim di tingkat lokal juga diharapkan dapat berkontribusi terhadap upaya mitigasi untuk mengurangi emisi Gas $\mathrm{Ru}-$ mah Kaca serta upaya mitigasi dan adaptasi untuk meningkatkan kapasitas seluruh pihak dalam menghadapi dampak perubahan iklim. Salah satu upaya lokal yaitu yang dilaksanakan oleh masyarakat mengatasi perubahan mulai ditunjukkan pada masyarakat Desa Pagerwangi. Pengelolaan lingkungan yang dilakukan di Desa Pagerwangi dikatakan berhasil, hal tersebut terbukti dengan adanya penghargaan kampung iklim yang diterima dari Kementerian Lingkungan Hidup. Tujuan dari pengelolaan lingkungan di Desa Pagerwangi berhasil karena adanya keterlibatan semua masyarakat dalam rangka mewujudkan lingkungan yang sehat. 


\section{Jurnal Pendidikan dan Pemberdayaan Masyarakat, 4 (1), March 2017 - 84}

\section{Mustangin}

Pengelolaan lingkungan yang dilakukan di masyarakat Desa Pagerwangi merupakan pengelolaan lingkungan yang berbasis masyarakat. Hal tersebut didasarkan pada keterlibatan penuh masyarakat dalam mengupayakan perbaikan lingkungan sendiri.

Program Pengelolaan Lingkungan di Desa pangerwangi awalnya tercipta melalui inisiasi organisasi yang berbasis masyarakat yang ada di desa pangerwangi. Organisasi di tingkat desa yang digagas dalam rangka mengatasi perubahan iklim. Organisasi berbasis masyarakat menurut (Vermeulen, Minkoff, \& van der Meer, 2016) penyediaan berbagai layanan dan kegiatan untuk warga lingkung-an tersebut, termasuk layanan dalam rangka peningkatan kapasitas masyarakat. Organisasi ini berbentuk lembaga yang kemudian dinamakan dengan Lembaga Keswadayaan Masyarakat (LKM) Rukun Wangi, lembaga masyarakat ini mampu menggerakkan masyarakat Desa Pagerwangi untuk dapat berperan serta dalam upaya bersama meng-atasi perubahan iklim di desa pagerwangi.

Berdasarkan Profil dari Lembaga Keswadayaan Masyarakat (LKM) Rukun Wangi yang ditulis tahun 2009 bahwa LKM Rukun Wangi dibentuk sebagai implementasi dari Program Nasional Pemberdayaan Masyarakat Mandiri Perkotaan sebagai institusi yang mengakar kemasyarakat, oleh masyarakat LKM Rukun Wangi diberi kepercayaan untuk berupaya untuk mencoba menanggulangi kemiskinan yang terjadi di desa Pagerwangi, Artinya LKM Rukun Wangi yang berdaya ini mampu menjadi motor penggerak masyarakat untuk menanggulangi kemiskinan secara berkelanjutan. sekaligus akan menjadi kancah pembelajaran masyarakat. Melalui wadah Pimpinan kolektif ini masyarakat diajak untuk berdialog bersama untuk dapat memahami segala permasalahan yang ada dalam lingkungan mereka sendiri. Belajar memahami faktor-faktor yang berkaitan langsung dengan interaksi sosial maupun yang ada hubungannya dengan kepedulian masyarakat lokal terhadap lingkungannya sendiri. Perhatian dan pemahaman terhadap keadaan realistis ini diharapkan dapat mendorong kesadaran kritis yang dapat menggerakan masayarakat untuk memiliki inisiatif untuk melakukan perubahan-perubahan secara kolektif maupun secara individual menuju kearah nilainilai yang lebih baik dalam kehidupannya bermasayarakat. Lebih lanjutnya lagi masyarakat dapat menciptakan kesadaran kolektif di dalam mengantisipasi permasalahan dan mencari solusi terhadap segala sesuatu permasalahan yang muncul di masyarakat, sehinga masyarakat dapat menyusun kebijakan-kebijakan berdasarkan prioritas kebutuhan lingkungan setempat.

Hasil keputusan dan kebijakan ini diharapkan menjadi sesuatu yang tepat sasaran dan terarah, terutama di dalam mengatasi permasalahan kemiskinan berdasarkan fakta dan kenyataan itulah maka LKM di bentuk oleh masyarakat agar dapat memberikan ruang dan kesempatan kepada semua warga masyarakat untuk saling mengkoreksi dan memantau perencanaan dan pemabangunan yang ada di desanya.

LKM Rukun Wangi sebagai organisasi masyarakat warga menjadi sebuah, media pembelajaran bagi masyarakat untuk memberikan jalan keluar dari masalah yang sedang dihadapi oleh masyarakat secara luas apalagi yang berhubungan dengan masyarakat miskin. LKM Rukun Wangi muncul penguatan akan pemahaman kelembagaan masyarakat yang bersifat lokal, dan ke depannya diharapkan menjadi motor penggerak dalam melembagakan dan membudayakan kembali nilai-nilai kemanusiaan dan kemasyarakatan sebagai nilai utama yang melandasi aktivitas penanggulangan kemiskinan di perkotaan.

\section{Keterlibatan Perempuan dalam Aksi Pengelolaan Lingkungan}

Desa Pangerwangi adalah salah satu desa yang sudah mendapat penghargaan Program Kampung Iklim (Proklim) yaitu sebuah penghargaan untuk kampung yang sudah dinilai oleh Kementerian Lingkungan Hidup sudah melakukan upaya mitigasi dan adaptasi terhadap perubahan iklim. Adanya penghargaan tersebut dikarenakan karena adanya gerakan yang aktif dari LKM Rukun Wangi itu sendiri. LKM Rukun Wangi memiliki program kerja yang memiliki fokus terhadap perbaikan lingkungan sekitar. 


\section{Jurnal Pendidikan dan Pemberdayaan Masyarakat, 4 (1), March 2017 - 85}

M. Mustangin

Untuk mengimplementasikan program kerja tersebut LKM Rukun Wangi turut serta melibatkan peran perempuan sebagai salah satu sasarannya.

Strategi yang dilakukan Lembaga Keswadayaan Masyarakat (LKM) Rukun Wangi tersebut dengan memanfaatkan perkumpulan-perkumpulan (kelompok) masyarakat yang sudah ada. Di masyarakat perkumpulan ibu-ibu di posyandu yang dipilih, karena memiliki pertemuan yang terjadwal. Hal tersebut juga didukung oleh pernyataan dari Slamet (dalam Anwas, 2013) bahwa salah satu cara meningkatkan partisipasi dalam masyarakat adalah perlunya ditumbuhkan berbagai lembaga-lembaga nonformal yang ada di masyarakat, contohnya adalah Posyandu.

Berdasarkan beberapa pandangan tersebut strategi LKM Rukun Wangi menjadi sebuah langkah yang tepat dalam rangka mencapai partisipasi perempuan dalam aksi pengelolaan lingkungan. Pertemuan di Posyandu dilakukan secara rutin dan keterlibatan perempuan menjadi hal yang utama, sehingga program pengelolaan lingkungan dapat berjalan dengan ikut terlibat dalam kegiatan yang dilakukan di posyandu. Posyandu tersebut dipilih sebagai langkah awal menumbuhkan kesadaran masyarakat untuk berperan serta dalam rangka mengatasi perubahan iklim tersebut. Selain itu perkumpulan posyandu dipilih oleh LKM Rukun Wangi sebagai langkah awal untuk memberikan pengetahuan dalam rangka pengelolaan lingkungan, hal tersebut seperti yang diuraikan oleh Egaga \& Akinwumi (2015) Program pendidikan bisa disalurkan melalui klub, organisasi, kelompok sosial-budaya dan agama dan bentuk lain dari pertemuan. Aspek rutinitas pertemuan para ibu-ibu pada kegiatan posyandu menjadi alasan unsur utama pelibatan perempuan dilakukan. Adanya Posyandu sebagi basis perkumpulan para perempuan mempermudah implementasi program pengelolaan lingkungan berbasis masyarakat. Sehingga pemilihan Posyandu tersebut menurut Yenti (2013) ada kaitannya untuk meningkatkan peran dan fungsi organisasi perempuan di tingkat lokal sebagai wadah pemberdayaan perempuan agar dapat terlibat secara aktif dalam program pembangunan pada wilayah tempat tinggalnya.

Posyandu yang anggotanya terdiri dari para perempuan penting dilibatkan, karena seorang ibu memiliki peran penting untuk proses pendidikan, hal tersebut juga yang menjadi salah satu pertimbangan LKM Rukun Wangi dalam melibatkan peran serta perempuan dalam posyandu. Sebagaimana hal tersebut didukung oleh pernyataan Dana (dalam Chaesfa \& Pandjaitan, 2013) bahwa perempuan dapat menjadi pendidik lingkungan. Perempuan atau ibu merupakan media edukasi pertama bagi anak-anak. Melalui ibu, pendidikan dan penyadaran mengenai kepedulian terhadap lingkungan dapat ditanamkan pada anak-anak sejak dini. Perilaku dalam pengelolaan lingkungan secara langsung akan menjadi model yang dapat mempengaruhi perilaku anakanaknya.

Selain karena alasan tersebut, LKM Rukun Wangi percaya bahwa perempuan akan mampu memberikan pengaruh terhadap keterlibatan yang lainnya dari suaminya bahkan rekan sesama perempuannya. Pola keterlibatan perempuan di Desa Pagerwangi dapat dilihat bahwa masalah lingkungan yang ada di masyarakat dapat dipecahkan dengan melibatkan peran perempuan. Pola keterlibatan perempuan dalam rangka pengelolaan lingkungan di Desa Pagerwangi dapat dilihat dari Gambar 1.

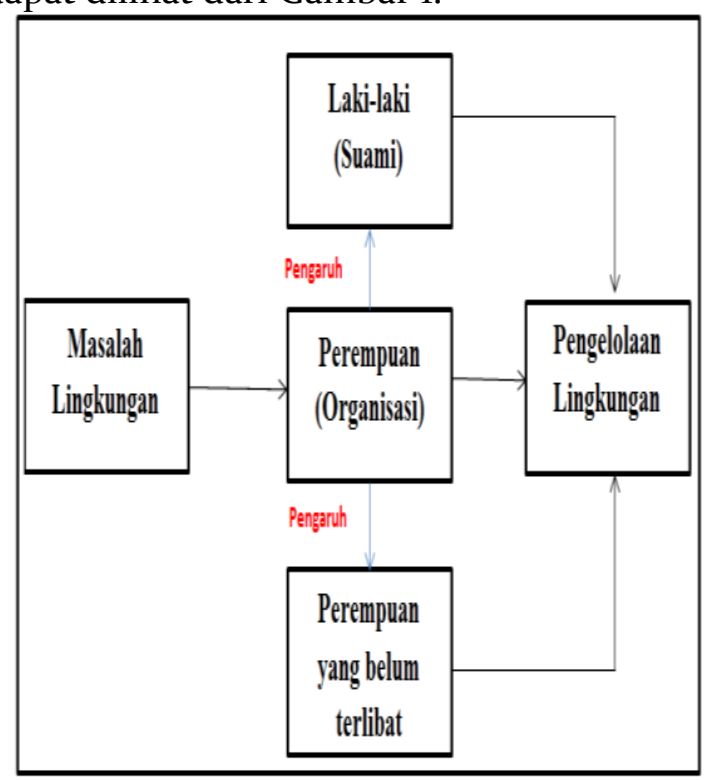

Gambar 1. Pola Keterlibatan Perempuan untuk Aksi Pengelolaan Lingkungan 


\section{Jurnal Pendidikan dan Pemberdayaan Masyarakat, 4 (1), March 2017 - 86 \\ M. Mustangin}

Perempuan Desa Pagerwangi yang terlibat dalam kegiatan posyandu diberikan pemahaman awal untuk dapat menjadi pelaku utama dalam pengelolaan sampah yang menjadi salah satu konsentrasi dalam pengelolaan lingkungan. Selanjutnya para perempuan Desa Pagerwangi tersebut mengajak peran serta para perempuan lainnya yang belum terlibat dalam program. Perempuan desa pagerwangi juga penyambung lidah dari Tim LKM Rukun Wangi untuk beberapa program pengelolaan lingkungan bagi pihak laki-laki atau suami. Sehingga hal tersebut menjadi efektif untuk cara meningkatkan partisipasi masyarakat. Proses penyebaran informasi menjadi lebih efektif.

Keterlibatan perempuan dalam rangka aksi pengelolaan lingkungan selain yang dilakukan seperti yang diatas juga dapat dilihat dari segi praktik penilaian pelibatan perembuan dibedakan atas tahapan pelibatan perempuan seperti yang ditulis oleh Suyono (dalam Anwas, 2013) yaitu tahap awal atau tahap perluasan jangkauan, tahap pembinaan, tahap pelembagaan atau pembudayaan serta tahapan akhir.

Tahapan awal atau perluasan jangkauan dengan melibatkan para perempuan dalam kegiatan yang praktis, intinya tahapan ini sebagai langkah untuk membuat sasaran tertarik. Sehingga para perempuan terlibat dalam program pengelolaan lingkungan tersebut. Salah satu program yang melibatkan perempuan adalah program bank sampah. Awal mulanya berasal dari kegiatan tim dari LKM Rukun Wangi yang memungut sampah setiap harinya dari tiap-tiap rumah tangga di Desa Pagerwangi tersebut. Saat mengumpulkan sampah di rumah warga Tim LKM Rukun Wangi mengenalkan adanya program Bank Sampah. Masyarakat diajak untuk terlibat dalam program Bank Sampah dengan tidak hanya membuang sampah pada tempatnya namun turut mengumpulkan dan kemudian memilah sampah untuk kemudian disalurkan ke Bank Sampah tersebut.

Tahapan Pembinaan dilakukan setelah tahapan awal dilaksanakan, adanya komunikasi yang dilakukan kepada masyarakat akan direspon oleh masyarakat. Pada program Bank Sampah dalam rangka pengelolaan lingkungan tersebut terjadi respon yang beragam, ada masyarakat yang dengan terbuka terus terlibat terhadap program, ada masyarakat yang acuh terhadap program. Dalam mewujudkan pengelolaan lingkungan berbasis masyarakat di desa Pangerwangi bukanlah hal yang mudah, mengingat bahwa setiap ada gerakan perubahan pasti ada yang pro dan kontra. Dalam melakukan perubahan perlu adanya perubahan pada diri masyarakat tersebut juga mengubah kesadaran, kebiasaan, dan menerapkan hal-hal baru dan itu bagi masyarakat bukanlah hal yang mudah, semua itu membutuhkan strategi guna mengaktifkan masyarakat untuk terlibat dalam pengelolaan lingkungan.Sehingga perlu adanya pembinaan kepada kelompokkelompok perempuan. Dalam hal ini LKM Rukun Wangi melakukan pembinaan-pembinaan kepada masyarakat dengan mengefektifkan lagi komunikasi kepada para perempuan. Hal tersebut dilakukan oleh LKM Rukun Wangi dengan cara bergabung dengan program posyandu yang diadakan sekali dalam sebulan dan pemberian makanan tambahan (PMT) bagi ibu-ibu yang memiliki balita. Para ibu yang datang ke Posyandu diajak untuk memilah sampah yang ada di rumah untuk kemudian ditukar dengan kebutuhan pokok. dari awalnya Tim LKM Rukun Wangi datang ke rumah-rumah untuk mengambil sampah, kemudian dibuatlah strategi yang lebih efektif yaitu datang ke kegiatan pertemuan kelompok untuk melakukan pembinaan lebih lanjut untuk para perempuan Desa Pagerwangi. Hal tersebut dilakukan untuk memberikan pengetahuan serta pemahaman awal pengelolaan lingkungan kepada masyarakat.

Selanjutnya tahap pelembagaan atau pembudayaan, di tahap ini komunikasi terjadi antar individu ke individu lain. Para ibu yang terlibat dalam program Bank Sampah saling memberikan informasi kepada yang lainnya untuk terlibat secara langsung. Para ibu yang terlibat secara aktif ikut mengkampanyekan program bank sampah dalam upaya mempengaruhi individu yang masih pasif dalam program bank sampah. Dalam tahapan ini peran LKM Rukun Wangi tidak begitu dominan karena secara aktif para ibu yang terlibat dalam program bank sampah yang mengambil peran dalam rangka men- 


\section{Jurnal Pendidikan dan Pemberdayaan Masyarakat, 4 (1), March 2017 - 87}

M. Mustangin

dukung jalannya program. Tim LKM Rukun Wangi bertindak sebagai pemberi arahan yang perlu dilakukan berikutnya atau bertukar pengalaman terhadap pemecahan masalah yang mungkin dihadapi.

Tahapan Akhir lebih kepada pemberian penghargaan kepada usaha yang dilakukan oleh perempuan ini. penghargaan ini ditujukan untuk merangsang perempuan yang terlibat untuk terus terlibat dalam keberlanjutan program. Penghargaan yang didapat sebagai wujud apresiasi terhadap keterlibatan perempuan salah satunya adalah dengan diraihnya penghargaan kampung iklim. Penghargaan ini tidak lepas dari peran serta perempuan dalam bertindak. Diketahui bahwa adanya kampung iklim ini awal mulanya adalah adanya inisiasi pertama dari pihak perempuan.

Keterlibatan perempuan yang awalnya dilakukan dengan mengumpulkan dan memilah barang bekas telah memberikan dampak pelaksanaan program yang selanjutnya. Diketahui di Desa Pagerwangi telah dibentuk Rumah Kompos Pagerwangi sebagai salah satu wadah masyarakat berbagi pengetahuan untuk pengelolaan lingkungan. Rumah Kompos Pagerwangi ini menjadikan Posyandu sebagai basis pendidikan nonformal bagi perempuan untuk pengelolaan sampah, yang salah satu kegiatannya adalah daur ulang sampah untuk barang-barang yang memiliki nilai jual. Dengan adanya Rumah Kompos Pagerwangi ini masyarakat diberikan keterampilan dalam mengelola sampah rumah tangga dan hal tersebut membuat para perempuan di Desa Pagerwangi semakin tertarik untuk terlibat dalam kegiatan pengelolaan lingkungan.

Beberapa kegiatan yang melibatkan penuh tenaga kerja laki-laki, para perempuan bertindak sebagai penyedia urusan makanan. Hal tersebut sudah menjadi kebiasaan di masyarakat dalam kegiatan gotong royong atau kerja bakti perempuan terlibat dalam urusan dapur. Kegiatan seperti itu sudah menjadi hal yang sudah disepakati di dalam masyarakat. hal tersebut juga terjadi pada perempuan di Desa Pagerwangi, keterlibatan perempuan sebagai penyedia urusan logistik yang dibutuhkan untuk memacu semangat para suami mereka yang sedang bekerja.

\section{SIMPULAN}

Keterlibatan perempuan dalam rangka pengelolaan lingkungan untuk mengatasi perubahan iklim dilakukan secara langsung. Para perempuan terlibat dari awal program hingga keberlanjutan program. Keterlibatan perempuan secara langsung terjadi pada program yang ada kaitannya dengan pengelolaan sampah rumah tangga. Keterlibatan perempuan dilakukan melalui organisasi yang ada di masyarakat Desa Pagerwangi yaitu Posyandu.

Perempuan terlibat juga sebagai penyebar informasi guna implementasi gerakan pengelolaan lingkungan. Keterlibatan perempuan dapat mempengaruhi para perempuan lainnya untuk ikut terlibat dalam pengelolaan sampah tersebut. Sehingga proses penyadaran antara perempuan yang belum terlibat dapat terjalin karena adanya proses persuasi dari para perempuan itu sendiri. selanjutnya para perempuan juga sebagai penyambung lidah antara Tim LKM Rukun Wangi dengan para suami untuk ikut terlibat dalam pengelolaan lingkungan tersebut.

Keterlibatan masyarakat dapat dilihat ditingkatkan dilihat dari beberapa tahapan peningkatan keterlibatan perempuan itu sendiri. Tahapan tersebut terdiri atas tahap awal atau tahap perluasan jangkauan, tahap pembinaan, tahap pelembagaan atau pembudayaan serta tahapan akhir. Dari tahapan tersebut dapat dilihat bagaimana perempuan terlibat dalam gerakan pengelolaan sampah sebagai salah satu faktor yang menjadi fokus dalam pengelolaan lingkungan.

\section{DAFTAR PUSTAKA}

Anwas, O. M. (2013). Pemberdayaan masyarakat di era global. Bandung: Alfabeta.

Astuti, T. M. P. (2012). Ekofeminisme dan peran perempuan dalam lingkungan. Indonesian Journal of Conservation, $1(1)$.

Boateng, C. ., \& Boateng, S. . (2015). Tertiary institutions in Ghana curriculum 
coverage on climate change: Implications for climate change awareness. Journal of Education and Practice, 6(12), 99-106. Retrieved from http://www.iiste.org/Journals/index.ph $\mathrm{p} / \mathrm{JEP} /$ article/view/21886

Chaesfa, Y., \& Pandjaitan, N. K. (2013). Women's perception of environmental and waste management participation in household (The case of Babakan Village, District Dramaga, Bogor Regency, West Java Province). Sodality: Jurnal Sosiologi Pedesaan, 1(2), 165-181. http://doi.org/10.22500/SODALITY.V1I2 .9401

Egaga, P. I., \& Akinwumi, A. S. (2015). Gender and environmental sustainability: Issues and problems involved for persons with special needs in Nigeria. Journal of Education and Practice, 6(30), 184-187. Retrieved from http://files.eric.ed.gov/fulltext/EJ108132 3.pdf

Elhaq, I. H., \& Satria, A. (2011). Persepsi pesanggem mengenai hutan mangrove dan partisipasi pesanggem dalam pengelolaan tambak mangrove ramah lingkungan model empang parit. Sodality: Jurnal Sosiologi Pedesaan, 5(1). http://doi.org/10.22500/sodality.v5i1.582 9

Francis, N. P. (2014). Climate change and implication for senior secondary school financial accounting curriculum development in Nigeria. Journal of Education and Practice, 5(26), 153-157. Retrieved from http://www.iiste.org/Journals/index.ph $\mathrm{p} / \mathrm{JEP} /$ article/view/15957

Hasani, Q. (2012). Konservasi sumberdaya perikanan berbasis masyarakat, implementasi nilai luhur budaya Indonesia dalam pengelolaan sumberdaya alam. AQUASAINS, 1(1). Retrieved from http://jurnal.fp.unila.ac.id/index.php/JP $\mathrm{BP} /$ article/view/18

Ife, J., \& Tesoriero, F. (2008). Alternatif pengembangan masyarakat di era globalisasi community development :
OPAC USU Library. (Sastrawan Manulang, Ed.) (Edisi Ke-3). Yogyakarta: Pustaka Pelajar. Retrieved from

http://digilib.usu.ac.id/buku/8787o/Alt ernatif-pengembangan-masyarakat-diera-globalisasi-communitydevelopment.html

Kementerian Lingkungan Hidup. (2015). program kampung iklim klhk mendukung -ketersediaan air. Diakses tanggal 2 Maret 2015 dari http://www.menlh.go.id/programkampung-iklim-klhk-mendukungketersediaan-air/.html

Okoli, J. N., \& Ifeakor, A. C. (2014). An overview of climate change and food security: Adaptation strategies and mitigation measures in Nigeria. Journal of Education and Practice, 5(32), 13-19. Retrieved from http://www.iiste.org/Journals/index.ph $\mathrm{p} / \mathrm{JEP} /$ article/view/16708

Redaksi Butaru. (2011). Profil wilayah: kewajiban kita dibalik keindahan wilayah pesisir Bali. Buletin Tata Ruang, hal. 9-13

Sagala,S. dkk. (2014). Tindakan penyesuaian petani terhadap dampak perubahan iklim. studi kasus Kabupaten Indramayu. Working Paper Series No. 6 Resilience Development Initiative

Sarwono, B. K. (2010). Pemaknaan kaum perempuan urban terhadap isu pemanasan global dan lingkungan di media. Jurnal Ilmu Komunikasi,8 (2), 178-190

Sohail, M. (2014). Women empowerment and economic development-an exploratory study in Pakistan. Journal Of Business Studies Quarterly, 5 (4), 210-221

Vermeulen, F., Minkoff, D. C., \& van der Meer, T. (2016). The local embedding of community-based organizations. Nonprofit and Voluntary Sector Quarterly, 45(1), 23-44. http://doi.org/10.1177/o89976401455893 3

Undang-Undang Republik Indonesia Nomor 
Jurnal Pendidikan dan Pemberdayaan Masyarakat, 4 (1), March 2017 - 89

M. Mustangin

17 Tahun 2004 Tentang Pengesahan Kyoto Protocol To The United Nations Framework C'onvention On Climate Change (Protokol Kyoto Atas Konvensi Kerangka Kerja Perserikatan BangsaBangsa Tentang Perubahan Iklim)

Widiarti, A. \& Hiyama, C. (2012). Prospek pelibatan perempuan dalam rehabilitasi hutan. (Yayan Indriatmoko, dkk, Ed). Dari Desa ke Desa Dinamika Gender dan Pengelolaan Kekayaan Alam. Jakarta: Center for International Forestry Research (CIFOR)

Yenti, Z. (2013). Perempuan penambang perahu di objek wisata Danau Sipin Kota Jambi: Studi tentang pemberdayaan perempuan dalam memanfaatkan dan melestarikan lingkungan. Media Akademika, 28(1). Retrieved from http://ejournal.iainjambi.ac.id/index.php/medi aakademika/article/view/172

Yuliana, A., \& Dewy, P. (2012). Mengurai realita pemiskinan perempuan di tengah konflik sumber daya alam: merekam kasus-kasus konflik sumber daya alam. Dalam Risma Umar (Ed)). Jakarta: Solidaritas Perempuan 